\title{
Protein supplementation of steers grazing tobosa- grass in spring and summer
}

\author{
JOHN S. PITTS, F.T. MCCOLLUM, AND CARLTON M. BRITTON
}

\begin{abstract}
Pitts is a former research associate, Texas Tech Univ., Lubbock; McCollum is associate professor, Animal Science Dept., Oklahoma State Univ., Stillwater; and Britton is professor, Dept. of Range and Wildlife Management, Texas Tech Univ.
\end{abstract}

\begin{abstract}
A 3-year study evaluated weight gain, blood urea nitrogen (BUN), and fecal nitrogen (FN) of beef steers fed $0.00,0.34$, or 0.68 $\mathrm{kg} / \mathrm{hd} / \mathrm{day}$ of cottonseed meal ( $41 \% \mathrm{CP}$ ) while grazing mesquite (Prosopis glandulosa var. glandulosa Torr.)/tobosagrass (Hilaria mutica [Buckl.] Benth.) range between April and July. Mixed breed beef steers (avg wt $230 \mathrm{~kg}$ ) were allocated to three 6-pasture grazing cells and group-fed prorated amounts of supplement 3 days a week. Individual weights were recorded every 21 days. Crude protein in clipped forage samples remained above $\mathbf{7 . 0 \%}$ except in July, 1985 (6.5\%). Gain response varied among periods within year but the primary effects occurred in the first $\mathbf{4 0}$ to $\mathbf{6 0}$ days of grazing. In 1985, daily gains over 92 days were $0.38,0.44$, and $0.67 \mathrm{~kg} / \mathrm{hd} / \mathrm{day}$ for the $0.00,0.34$, and $0.68 \mathrm{~kg}$ supplement groups, respectively. In 1986 and 1987, daily gains during 85-day trials were $0.65,0.66$, and $0.71 \mathrm{~kg} / \mathrm{hd} / \mathrm{day}$ and $0.98,1.08$, and 1.07 $\mathrm{kg} / \mathrm{hd} / \mathrm{day}$, respectively. Blood and feces were collected from 10 steers in each treatment group on each weigh date during the first 2 years. The $0.68 \mathrm{~kg} / \mathrm{hd} / \mathrm{day}$ supplement maintained higher $(P<0.05)$ BUN and FN than the control group but response to $0.34 \mathrm{~kg}$ supplement was inconsistent. Performance and BUN data suggested that protein concentrate was not the appropriate supplement for steers grazing tobosagrass in the spring and summer.
\end{abstract}

Key Words: cattle, range, supplementation, weight gain, fecal nitrogen, blood urea nitrogen

Tobosagrass ( Hilaria mutica [Buckl.] Benth.) range covers large areas of the arid southwestern United States and northern Mexico (Neuenschwander et al. 1975). Despite its coarse, unpalatable nature, the extensive distribution of this species makes it an important forage resource for ranchers of this region (Anderson 1988). In western Texas, crude protein (CP) content in current year's growth declined from 16.0 in April to $5.0 \%$ in July while in vitro digestible organic matter (DOM) declined from 55 to $35 \%$ (Britton and Steuter 1983). Standing dead forage contained from 14 to $23 \%$ DOM. Forage intake as low as $1.3 \%$ of body weight was reported for steers grazing spring and summer tobosagrass in western Texas (Reeves 1987).

Considering the low nutritive value of this forage during the summer, performance of grazing animals would be expected to be low. Anderson (1988) observed summer weight gains of only 0.11 to $0.38 \mathrm{~kg} / \mathrm{hd} /$ day by heifers grazing in southern New Mexico. Protein supplementation has improved cattle performance on summer range in other regions but has not been tested on tobosagrass range. Natural protein supplements (38-41\% CP) fed at a rate of $0.45 \mathrm{~kg} / \mathrm{hd} /$ day increased weight gain of growing cattle grazing tallgrass prairie (Lusby et al. 1981, McCollum and Lusby 1989) and sandsage prairie (Shoop and Mcllvain 1971) in Oklahoma.

Published with approval of College of Agricultural Sciences, Texas Tech Univ. Publication No. T-9-600 and with approval of Oklahoma Agr. Exp. Sta., Publication No. J-5973.

Manuscript accepted 10 June 1991.
Similar results were reported with steers grazing shortgrass prairie in northeastern New Mexico (Shafer et al. 1985) but results of other studies on shortgrass prairie have been inconsistent (Launchbaugh and Brethour 1968, Stanton et al. 1988, Stanton and Shoop 1989).

Blood and fecal constituents may potentially be used as indicators of protein intake and status of ruminants. Relationships between fecal nitrogen (FN) and dietary nitrogen have been reported for cattle (Hinnant 1979, Holechek et al. 1982, McCollum 1990), deer, and elk (Leslie and Starkey 1985). Blood urea nitrogen (BUN) has been positively correlated with dietary nitrogen in sheep (Preston et al. 1965), deer (Seal et al. 1978), and cattle (Preston et al. 1978).

The primary objective of this study was to determine if protein supplementation would enhance performance of steers grazing tobosagrass range in the spring and summer. A secondary objective was to determine if BUN and FN could be used as indices of protein status.

\section{Materials and Methods}

\section{Study Area}

The study was conducted on the Texas Tech Experimental Ranch $\left(101^{\circ} 11^{\prime} \mathrm{W} ., 32^{\circ} 58 \mathrm{~N}\right.$.) $10 \mathrm{~km}$ southeast of Justiceburg, Garza County, in the Texas Rolling Plains. Mean elevation is 800 $\mathrm{m}$. The region has a semiarid, continental climate. Average length of the growing season is 216 days (Richardson et al. 1965). Average precipitation is $478 \mathrm{~mm}$ with about $50 \%$ of mean annual precipitation occuring during the months of April through July. Drought is common. Total annual rainfall was above average in each year of this study.

The area is primarily a Clay Flat range site with gently sloping Stamford clay soils (fine, montmorillonitic, thermic Typic Chromusterts). Tobosagrass is the dominant forage with alkali sacaton (Sporobolus airoides [Torr.] Torr.) present in depressions. The more upland areas produce buffalograss (Buchloe dactyloides [Nutt.] Engelm.). Mesquite (Prosopis glandulosa var. glandulosa Torr.) covers the area and was suppressed with aerial herbicide applications in 1983. In excellent condition, average yearly forage production for this range site is $1,500 \mathrm{~kg} /$ ha (Richardson et al. 1965).

\section{Field Trials}

Crossbred (Bos taurus $\times$ Box indicus) beef steers (200-240 $\mathrm{kg} / \mathrm{hd}$ ) were randomly allocated (based on weight) to each of 3 , 6-pasture grazing cells in April of each year. Cell areas were 95, 91, and 68 ha with 27 to 57 steers stocked in each cell. Steers were rotated through the cells on 42-day cycles with length of stay in each pasture from 4 to 10 days.

Stocking rate for each cell was set based on standing crop at the start of each trial and estimated production for the current year assuming removal of $50 \%$ of available forage. An attempt was also made to maintain similar forage allowances in all 3 cells (Table 1). 
Table 1. Forage standing crop, treatment assignments, and herd sizes for supplementation trials conducted in 1985, 1986, and 1987 at the Texas Tech Experimental Ranch.

\begin{tabular}{|c|c|c|c|c|c|}
\hline Year & $\begin{array}{c}\text { Supplement } \\
\text { level }\end{array}$ & Cell & $\begin{array}{l}\text { Standing } \\
\text { crop }\end{array}$ & $\begin{array}{c}\text { Steers/ } \\
\text { cell }^{\mathbf{Q}}\end{array}$ & $\begin{array}{c}\text { Forage } \\
\text { allowance }\end{array}$ \\
\hline 1985 & $\begin{array}{c}(\mathrm{kg} / \text { head } / \text { day }) \\
0.0 \\
0.34 \\
0.68\end{array}$ & $\begin{array}{l}2 \\
3 \\
1\end{array}$ & $\begin{array}{c}(\mathrm{kg} / \mathrm{ha}) \\
690 \\
1010 \\
810\end{array}$ & $\begin{array}{l}57 \\
57 \\
57\end{array}$ & $\begin{array}{c}\text { (kg/head) }^{\mathbf{b}} \\
1111 \\
1192 \\
1350\end{array}$ \\
\hline 1986 & $\begin{array}{l}0.0 \\
0.34 \\
0.68\end{array}$ & $\begin{array}{l}1 \\
2 \\
3\end{array}$ & $\begin{array}{l}810 \\
490 \\
700\end{array}$ & $\begin{array}{l}37 \\
27 \\
27\end{array}$ & $\begin{array}{l}2078 \\
1649 \\
1739\end{array}$ \\
\hline 1987 & $\begin{array}{l}0.0 \\
0.34 \\
0.68\end{array}$ & $\begin{array}{l}3 \\
1 \\
2\end{array}$ & $\begin{array}{l}1730 \\
1420 \\
1570\end{array}$ & $\begin{array}{l}37 \\
40 \\
28\end{array}$ & $\begin{array}{l}3158 \\
3385 \\
5115\end{array}$ \\
\hline
\end{tabular}

"Only 150 head were monitored in the current trial; 21 head were used in another study.

${ }^{6}$ Total grass available per steer at the beginning of each grazing season.

Average residual standing crop during the grazing season was 836 $\mathrm{kg} / \mathrm{ha}, 663 \mathrm{~kg} / \mathrm{ha}$, and $1,574 \mathrm{~kg} / \mathrm{ha}$, for 1985 , 1986, and 1987 , respectively.

In 1985, 150 steers were purchased in March, pastured on wheat for 26 days then moved to the study site on 17 April. The cattle were weighed (Table 2) and allocated to treatment groups on 23 April. An additional 21 steers were allocated to the treatment groups at this time to increase the stocking rate in the cells but were not monitored as part of this experiment. Supplementation began at this time and continued until 23 July. In 1986, 91 steers arrived at the study site on $6 \mathrm{March}$ after wintering on dormant range in eastern New Mexico. The steers were weighed (Table 2) and allo-

Table 2. Weights and weight gains" by steers grazing tobosagrass and supplemented with cottonseed meal in 1985,1986, and 1987 at the Texas Tech Experimental Ranch.

\begin{tabular}{|c|c|c|c|c|c|}
\hline Year & $\begin{array}{c}\text { Trial } \\
\text { Length }\end{array}$ & $\begin{array}{c}\text { Supplement } \\
\text { Level }\end{array}$ & $\begin{array}{l}\text { Initial } \\
\text { Weight }\end{array}$ & $\begin{array}{c}\text { Final } \\
\text { Weight }\end{array}$ & $\begin{array}{l}\text { Daily } \\
\text { Gain }\end{array}$ \\
\hline 1985 & $\begin{array}{l}\text { (days) } \\
92\end{array}$ & $\begin{array}{c}\text { (kg/day) } \\
0.00 \\
0.34 \\
0.68 \\
\text { SE }\end{array}$ & $\begin{array}{r}(\mathbf{k g}) \\
235 \\
230 \\
235 \\
3\end{array}$ & $\begin{array}{r}(\mathrm{kg}) \\
271 \\
269 \\
291 \\
3\end{array}$ & $\begin{array}{l}(\mathrm{kg}) \\
0.38^{\mathrm{b}, \mathrm{c}} \\
0.42^{\mathrm{b}, \mathrm{e}} \\
0.60^{\mathrm{c}} \\
0.02\end{array}$ \\
\hline 1986 & 85 & $\begin{array}{r}0.00 \\
0.34 \\
0.68 \\
\text { SE }\end{array}$ & $\begin{array}{r}235 \\
241 \\
238 \\
5\end{array}$ & $\begin{array}{r}289 \\
296 \\
297 \\
6\end{array}$ & $\begin{array}{l}0.64 \\
0.65 \\
0.70 \\
0.02\end{array}$ \\
\hline 1987 & 85 & $\begin{array}{r}0.00 \\
0.34 \\
0.68 \\
\text { SE }\end{array}$ & $\begin{array}{r}212 \\
211 \\
211 \\
4\end{array}$ & $\begin{array}{r}294 \\
302 \\
301 \\
5\end{array}$ & $\begin{array}{l}0.97^{\mathrm{b}} \\
1.07^{\mathrm{c}} \\
1.06^{\mathrm{c}} \\
0.03\end{array}$ \\
\hline
\end{tabular}

Least squares means

b.c Column means are different, $P<0.01$

d.o Column means are different, $P=0.11$.

cated to treatments on 7 April; the trial began at this time and ended on 30 June. In 1987, 105 steers were wintered on the study site from 15 November to 11 April. On 11 April, the steers were weighed (Table 2) and allocated to treatment groups based on previous winter treatment and weight. The trial ended on 4 July. Cattle were administered a four-way vaccine (Clostridium chauvoei, $C$. septicum, $C$. novyi, and $C$. sordellii), a parasiticide (ivermectin), and growth implant (Ralgro) upon arrival at the study site each year. Steer weights were recorded on approximately 21-day intervals during the trials. All weights were recorded after 14 hours overnight period without feed and water.
Cottonseed meal (41\% CP, solvent extracted) was fed at either $0.00,0.34$, or $0.68 \mathrm{~kg} /$ head / day (as-fed basis). Cattle were groupfed a prorated amount of supplement 3 days per week. Supplement treatments were rotated among the 3 cells during the 3-year study (Table 1). Free choice mineral $(13 \% \mathrm{Ca}, 7 \% \mathrm{P}, 50 \% \mathrm{NaCl})$ was available at all times.

In 1985 and 1986, BUN and FN were monitored in 10 steers from each treatment group. The steers were randomly selected from the middle weight class (weight range $23 \mathrm{~kg}$ ) of each treatment group. At 1700 hour the evening before each weighing, this group was sorted from the main herd to facilitate sampling and minimize excitement of the animals prior to sampling. Blood and fecal samples were obtained and weights recorded between 0700 and 0800 hour the following morning. Two, $10-\mathrm{ml}$ blood samples were drawn via jugular puncture from each steer, immediately placed on ice, then allowed to coagulate while refrigerated. After coagulation, the samples were centrifuged at $3000 \mathrm{rpm}$ for $10 \mathrm{~min}$ and the serum was decanted and frozen. Urea nitrogen concentration was determined by urease assay (Chaney and Marbach 1962). Fecal samples were collected via rectal stimulation then stored frozen in plastic bags. Samples were thawed, dried in a forced-air oven at $40^{\circ}$ $C$, and ground through a 40-mesh screen prior to laboratory analyses. Fecal analyses included kjeldahl nitrogen $(\mathrm{N})$, dry matter, and ash (AOAC 1980). Fecal nitrogen concentration was expressed as a percentage of organic matter.

Forage CP was estimated from hand-clipped samples taken in each cell on or about the day cattle were weighed. Composite samples of grass and composite samples of forbs were collected in 1985. Samples of tobosagrass, alkali sacaton, other grass, and forbs were collected in 1986 and 1987. Samples were dried in a forced-air oven at $40^{\circ} \mathrm{C}$. Crude protein (kjeldahl $\mathrm{N} \times 6.25$ ) and dry matter were determined for each forage sample (AOAC 1980).

\section{Statistical Analyses}

Because the 3 supplementation treatments were rotated among the 3 grazing cells in this 3 -year study, a Latin square design was used for the analysis. A repeated measures analysis, with period as the repeated measurement, was used to analyze changes in steer weights every 21 days throughout the supplementation period (Damon and Harvey 1987). The YEAR $\times$ PERIOD, PASTURE $\times$ PERIOD, and TREATMENT $\times$ PERIOD interactions were significant, and subsequent analyses were completed within periods. Experimental units were individual animals. A protected least significant difference procedure was used to separate means (Damon and Harvey 1987).

For BUN and FN data, individual animals were considered experimental units in a completely randomized design with supplementation treatment and period as main effects in a factorial arrangement. Data collected in 1985 and 1986 were incorporated into the analysis as repeated measurements. The YEAR $\times$ TREATMENT interaction was significant for most variables and data were subsequently analyzed within year. When TREATMENT $\times$ PERIOD interactions were significant, simple effects of treatment were analyzed. A protected least significant difference procedure was used to separate means.

The use of animals as experimental units provided a conservative analysis because the animals were group-fed rather than individually fed. Group-feeding results in greater variation among animals within treatments as a result of uncontrolled and varied feed consumption by individuals. Hence, any significant differences observed among treatments are valid. A potential weakness of the analyses is the inability to discern smaller differences that would have been statistically significant with controlled, individualfeeding. In range production systems however, livestock are not individually fed, therefore the analyses we utilized should reflect 
differences encountered by livestock managers.

\section{Results and Discussion}

\section{Forage Crude Protein}

Forage CP was monitored as an index of plane of nutrition. It is acknowledged that selective grazing improves nutrient value of diets compared to available forage. However, forage CP is relatively easy to measure and is frequently used in the field to monitor plane of nutrition. The highest forage CP levels were measured around 1 May each year (Fig. 1). With the exception of levels in late April/early May, forage CP in 1985 and 1987 followed similar trends, declining to around $7 \%$ in July. In 1986, forage CP peaked

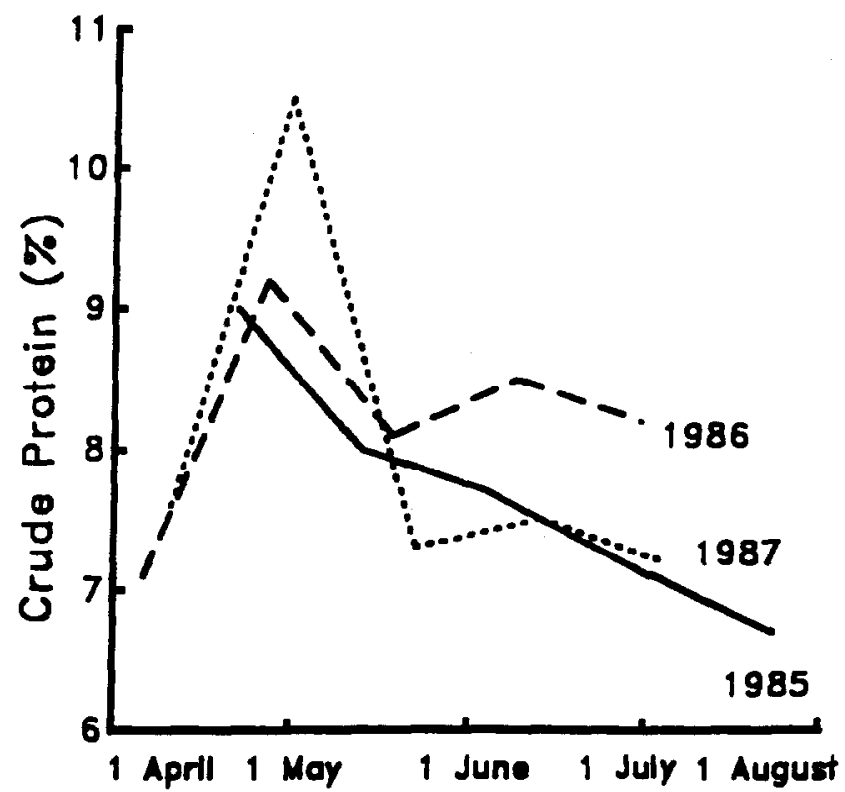

Fig. 1. Crude protein content (\% dry matter basis) of forage samples clipped from tobosagrass range during the 1985, 1986, and 1987 grazing seasons at the Texas Tech Experimental Ranch, Garza County, Texas.

at a concentration similar to 1985 but remained higher (about $8.1 \%)$ through the grazing season. Britton and Steuter (1983) reported a wider range of seasonal values with $\mathrm{CP}$ declining from $16.0 \%$ in April to $5.0 \%$ by July.

\section{Steer Performance}

Unsupplemented steers gained $0.38,0.64$, and $0.97 \mathrm{~kg} /$ day in 1985 , 1986, and 1987 , respectively (Table 2 ). The poorer overall performance in 1985 is partially due to low gains $(0.07 \mathrm{~kg} / \mathrm{hd} /$ day $)$ during the last 3 weeks of the trial. In subsequent years, grazing was terminated around $1 \mathrm{July}$. If the 1985 season had ended just prior to the final 3-week period, gains would have averaged 0.49 $\mathrm{kg} / \mathrm{head} /$ day. Anderson (1988) reported gains of 0.11 to 0.38 $\mathrm{kg} / \mathrm{head} /$ day, depending upon year, for heifers grazing tobosagrass in southern New Mexico during May and June.

In 1985, the low level of supplement tended ( $P=0.11$ ) to improve seasonal steer performance compared to that of the unsupplemented group (Table 2). Cumulative gain curves (Fig. 2) indicated that the advantage over unsupplemented cattle occurred during the first 42 days of the trial. Seasonal weight gain was greatest $(P<0.01)$ for the cattle receiving $0.68 \mathrm{~kg}$ supplement $/$ day. Weight gains during the first 42-day and final 21-day of the grazing season reflect this difference. From day 42 to 63 , rate of gain for the 0.68 $\mathrm{kg}$ /day group was slower than for the unsupplemented and 0.34 $\mathrm{kg} /$ day treatments. Based on the weight at 92 days and gain from day 63 to 92 , it appeared that the slow rate of gain was an artifact of fill at the end of 63 days. Supplement conversion efficiencies,
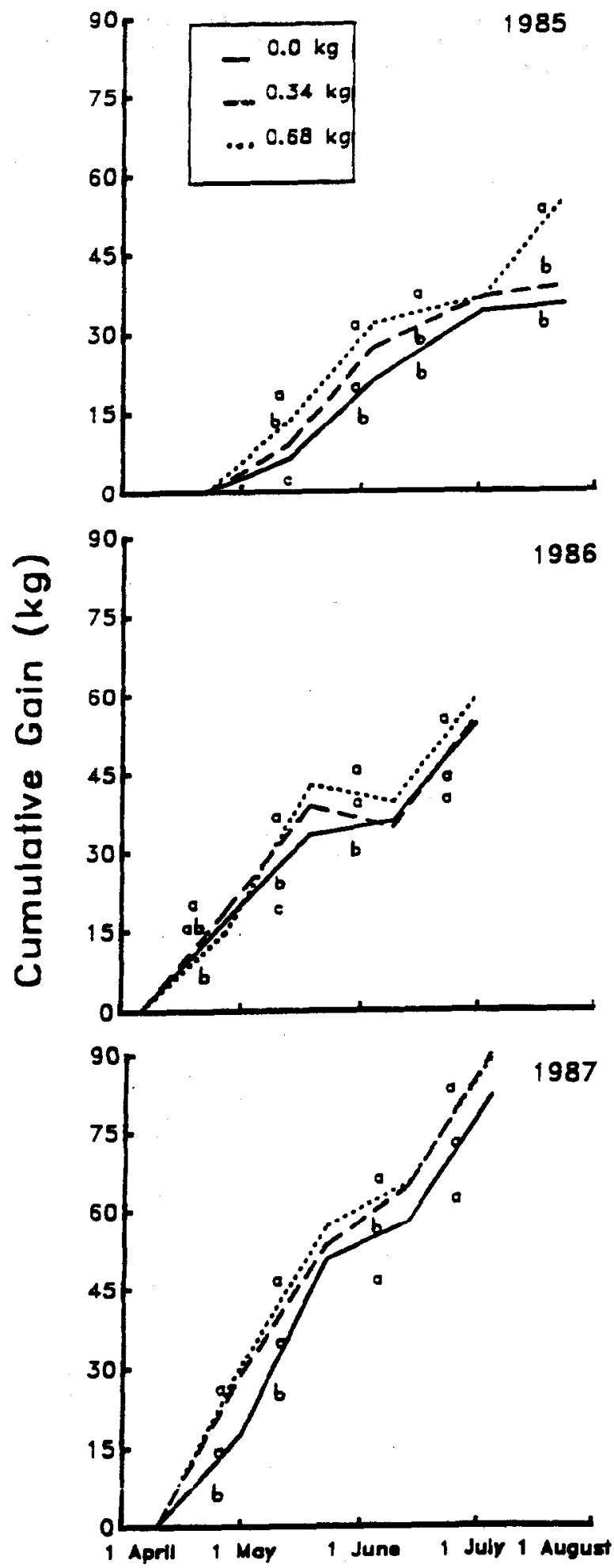

Fig. 2. Cumulative weight gains ( $\mathrm{kg} /$ head) by steers grazing tobosagrass range and supplemented with 3 levels of cottonseed meal.

$\mathrm{a}, \mathrm{b}, c$, Interval means are different, $P<0.05$.

expressed as $\mathrm{kg}$ supplement $/ \mathrm{kg}$ of additional weight gain, were 8.5 and 3.1 for the 0.34 and $0.68 \mathrm{~kg} /$ day treatments, respectively.

In 1986, neither level of supplementation improved seasonal gains $(P>0.10)$. Supplemented cattle gained more rapidly during the second 21-day interval of the trial, but the difference was forfeited by weight loss between days 42 and 63 . This loss was not recovered during the final trial period. 

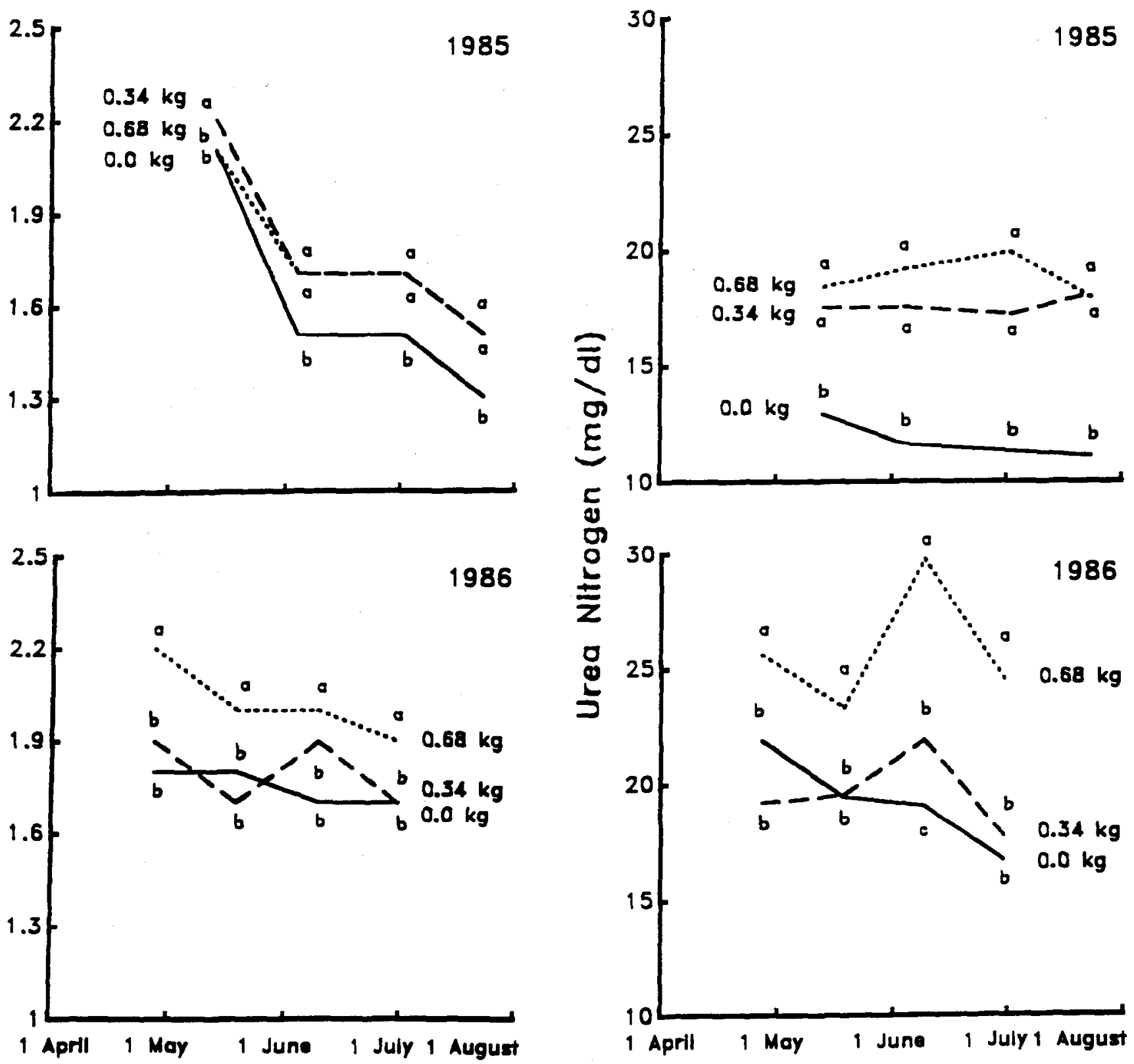

Fig. 3. Fecal nitrogen concentrations (\% organic matter basis) in steers graxing tobosagrass range and supplemented with 3 levels of cottonseed meal.

${ }_{a, b, c}$ Interval means are different, $P<0.05$.

Supplementation improved $(P<0.01)$ weight gain in 1987 but overall response was similar for both supplement treatments (Table 2). Cattle receiving $0.34 \mathrm{~kg} /$ day of supplement gained more weight than the unsupplemented group during the first 63 days of the trial (Fig. 1). The $0.68 \mathrm{~kg}$ / day group gained more weight during the first 42-days and maintained this advantage over the remainder of the trial. Supplement conversion efficiencies were 3.4 and $7.6 \mathrm{~kg}$ supplement $/ \mathrm{kg}$ additional gain for 0.34 and $0.68 \mathrm{~kg}$ supplement $/$ day, respectively.

In comparison to the $0.34 \mathrm{~kg} /$ day treatment, the higher level of supplement improved gains in 1985 only. Gain during the final 51 days of the 1985 trial accounted for $72 \%$ of the difference between the 2 groups. This was the only year in which grazing extended past the first week of July. Also, this is the only period in which protein levels in the forage dropped below $7 \%$.

Inconsistent responses to supplementation may be associated with CP in available forage remaining above $7 \%$ throughout the

Fig. 4. Blood urea nitrogen concentrations $(\mathrm{mg} / \mathrm{dl})$ in steers grazing tobosagrass range and supplemented with 3 levels of cottonseed meal. $\mathrm{a}, \mathrm{b}, \mathrm{c}$ Interval means are different, $P<0.05$.

trials. Protein supplementation may not improve forage digestion and intake and hence performance when diet $\mathrm{CP}$ is above 6 to $8 \%$ (Blaxter and Wilson 1963, Rittenhouse et al. 1970, McCollum and Horn 1990). The lack of a consistent response to supplementation may also be related to low daily intakes of tobosagrass resulting from low forage digestibility (Reeves 1987). Egan (1977) demonstrated that an intake response may not occur when forage CP is high relative to digestibility, regardless of protein content.

\section{Fecal Nitrogen and Blood Urea Nitrogen}

Fecal nitrogen fell within ranges reported for beef steers and heifers consuming forage diets (Hinnant 1979, Holechek et al. 1982, McCollum 1990). Fecal nitrogen appeared to reflect forage CP in the current study. In 1985, highest concentrations occurred in the spring and lowest concentrations in July (Fig. 3). All supplement groups followed a similar pattern but FN of the supplemented cattle was higher $(P<0.05)$ than that of the unsupplemented cattle in June and July. Seasonal changes in FN during 
1986 were not as pronounced as in 1985 . Fecal $\mathrm{N}$ was consistently higher $(P<0.05)$ in the cattle receiving the high level of supplement with little difference between the other 2 groups.

In 1985 , when gains were improved by supplementation, FN of the unsupplemented cattle dropped to $1.5 \%$ by June and stayed below $1.5 \%$ until the end of the season while the supplemented groups maintained $\mathrm{FN}$ at $1.7 \%$ until the final 21 days of the trial. In 1986, when performance was not affected by supplementation, FN of the unsupplemented cattle remained between 1.7 and $1.8 \%$ for the entire season.

Inconsistent weight gains at the various time intervals within a trial hindered any chance of correlating weight change and FN in the present study. Discrepancies in the relationship between FN and gain occurred primarily in the third 21-day interval of each trial. During these periods, gain tended to decline without an accompanying decline in FN. This incongruity suggested that fill, or an environmental factor, or a nutrient deficiency other than protein was limiting growth. Fecal $\mathrm{N}$ may provide estimates of diet N concentration (Hinnant 1979, Holechek et al. 1982, McCollum 1990) but not total nutritional status (i.e., energy balance).

Blood urea $\mathrm{N}$ concentration tended to decline across the grazing season but the change was not as marked as with FN (Fig. 4). Treatment influences on BUN were similar to those noted with FN. In 1985 , supplemented cattle had higher $(P<0.05)$ BUN concentrations than the unsupplemented cattle. But in 1986, only the cattle receiving $0.68 \mathrm{~kg}$ supplement/day had elevated BUN levels. A marked contrast was noted between the range of values in the first year and second year. Values ranged from 11 to $20 \mathrm{mg} / \mathrm{dl}$ in 1985 when supplementation improved performance, and 17 to $29 \mathrm{mg} / \mathrm{dl}$ in 1986 when a performance response was absent. In 1987 when growth responded to supplementation, BUN levels of unsupplemented cattle in an associated trial (Pitts 1989) were between 9 and $11 \mathrm{mg} / \mathrm{dl}$; supplementation increased BUN to around $13 \mathrm{mg} / \mathrm{dl}$.

Preston et al. (1965) suggested that $10.0 \mathrm{mg} / 100 \mathrm{ml}$ BUN indicated adequate protein intake in wether lambs while 7.0-8.0 $\mathrm{mg} / 100 \mathrm{ml}$ indicated adequate nitrogen intake in feedlot steers (Preston et al. 1978). Previous work demonstrated that level of protein intake influenced BUN but the balance of protein and energy in the diet had an equal if not more potent influence on BUN (Oltner and Wiktorsson 1983, Richardson 1984a,b). Richardson (1984b) indicated that BUN could be used as an index of protein status but its use would be enhanced by some estimate of energy intake relative to energy requirements. Increasing protein intake at a constant energy intake will elevate BUN while increasing energy intake at a constant protein intake will depress BUN concentrations. Hence, one could interpret the elevated BUN levels (in excess of 9 to $11 \%$ ), especially in 1986, as an indication of an energy deficit relative to protein intake. If this was the case, a supplement supplying a higher ratio of energy to protein might have improved performance. Based on the available data, it would appear that if BUN concentration in an unsupplemented steer is in excess of 11 to $12 \mathrm{mg} / \mathrm{dl}$ then protein concentrates may not be the supplement of choice. Instead supplements supplying a higher ratio of energy to protein may elicit better performance.

In summary, supplementation with cottonseed meal improved seasonal weight gains in 1985 and 1987 . Generally the effects were due to improved gains in the early part of the grazing season. Supplementation in July also appears to be a useful practice. The $0.34 \mathrm{~kg}$ cottonseed meal/head/day provided a gain response in 2 of 3 years while the higher level of feeding provided further improvement in only 1 year. If the cattle had been individually fed, it is possible that less variation among individuals within supplement groups would have occurred and significant treatment differences would have been more apparent. Blood analyses suggested that an energy supplement with a midrange protein content is possibly the more desirable supplement for yearlings grazing rangelands of this type during the spring months.

\section{Literature Cited}

Anderson, D.M. 1988. Seasonal stocking of tobosagrass managed under continuous and rotation grazing. J. Range Manage. 41:78-83.

AOAC. 1980. Official Methods of Analysis (13th Ed.) Assoc. of Off. Analy. Chem., Washington, D.C.

Blaxter, K.L., and R.S. Wilson. 1963. The assessment of crop husbandry technique in terms of animal production. Animal Prod. 3:51-61.

Britton, C.M., and A.A. Steuter. 1983. Production and nutritional attributes of tobosagrass following burning. Southwestern Natur. 28:347-352 .

Chaney, A.L., and E.P. Marbach. 1962. Modificd reagents for determination of urea and ammonia. Clin. Chem. 8:130-133.

Damon, R.A., Jr., and W.R. Harvey. 1987. Experimental Design, ANOVA, and Regression. Harper and Rowe, N.Y.

Egan, A.R. 1977. Nutritional status and intake regulation in sheep. VIII. Relationships between the voluntary intake of herbage by sheep and the protein/energy ratio in the digestion products. Aust. J. Agr. Res. 28:907-915.

Hinnant, R.T. 1979. Blood, rumen liquor, and fecal components as affected by dietary crude protein. M.S. Thesis. Texas A\&M Univ., College Station.

Holechek, J.L., M. Vavra, and D. Arthun. 1982. Relationships between performance, intake, diet nutritive quality and fecal nutritive quality of cattle on mountain range. J. Range Manage. 35:741-744.

Launchbaugh, J.L., and J.R. Brethour. 1968. Summer precipitation and steer gain interactions on supplemented shortgrass range. J. Range Manage. 21:145-148.

Leslie, D.M., and E.E. Starkey. 1985. Fecal indices to dietary quality of cervids in old-growth forests. J. Wildl. Manage. 49:142-146.

Lusby, K.S., G.W. Horn, and M.J. Dvorak. 1981. Energy vs protein supplementation of steers grazing native range in late summer and early fall. Oklahoma Agr. Exp. Sta. MP-112:36-38.

McCollum, F.T. 1990. Relationships among fecal nitrogen, diet nitrogen, and daily gain of steers grazing tallgrass prairie. Oklahoma Agr. Exp. Sta. MP-129:232-235.

McCollum III, F.T., and G.W. Horn. 1990. Protein supplementation of grazing livestock: A review. Prof. Anim. Sci. 6:1-16.

McCollum, F.T., and K.S. Lusby. 1989. Early summer supplements for weaned fall-born calves grazing tallgrass prairie. Oklahoma Agr. Exp. MP-127:37-39.

Neuenschwander, L.F., S.H. Sharrow, and H.A. Wright. 1975. Review of tobosagrass (Hilaria mutica). Southwestern Natur. 20:255-263.

Oltner, R., and H. Wiktorsson. 1983. Urea concentrations in milk and blood as influenced by feeding varying amounts of protein and energy to dairy cows. Livestock Prod. Sci. 10:456-467.

Pitts, J.S. 1989. Effect of protein supplementation on relationships among performance, nutrient intake, and blood and fecal components of steers grazing tobosagrass. PhD Diss., Oklahoma State Univ., Stillwater.

Preston, R.L., D.D. Schnakenberg, and W.H. Pfander. 1965. Protein utilization in ruminants. I. Blood urea nitrogen as affected by protein intake. J. Nutr. 86:281-287.

Preston, R.L., F.M. Byers, and K.R. Stevens. 1978. Estrogenic activity and growth stimulation in steers fed varying protein levels. J. Anim. Sci. 46:541- 546.

Reeves, G.W. 1987. Influence of protein supplementation on forage intake and dietary selectivity of grazing steers. M.S. Thesis, Texas Tech Univ., Lubbock.

Richardson, W.E., D.G. Grice, and L.A. Putnam. 1965. Soil survey of Garza County, Texas. USDA Soil Conserv. Serv.

Richardson, F.D. 1984a. The use of biochemical parameters to monitor the nutritional status of ruminants. 2 . The concentrations of blood metabolites in relation to protein and energy intakes, breed and time of sampling in growing cattle. Zimbabwe J. Agr. Res. 22:15-34.

Richardson, F.D. 1984b. The use of biochemical parameters to monitor the nutritional status of ruminants. 3. The influence of energy intake and sampling time on the relation between concentration of urea-nitrogen in the plasma of growing cattle and crude protein of the diet. Zimbabwe $J$. Agr. Res. 22:35-50.

Rittenhouse, L.R., D.C. Clanton, and C.L. Streeter. 1970. Intake and digestibility of winter range forage by cattle with and without supplements. J. Anim. Sci. 31:1215-1221. 
Seal, U.S., L.J. Verme, and J.J. Ozoga. 1978. Dietary protein and energy effects on deer fawn metabolic patterns. J. Wildl. Manage. 42:776-790. Shoop, M.C., and E.H. McIlvain. 1971. Efficiency of combining improvement practices that increase steer gains. J. Range Manage. 24:113-116. Shafer, M.G., M. Grigsby, and G.P. Lofgren. 1985. Protein supplementation on late surmmer grass. New Mexicu Agr. Exp. Sta. Prog. Rep. 39.
Stanton, T.L., D. Schutz, K.G. Odde, and R.S. Labore. 1988. Effect of protein supplementation of grazing steers during late summer. Colorado State Univ. Beef Prog. Rep. pp. 53-56.

Stanton, T.L., and M.C. Shoop. 1989. Protein and ionophore supplementation of spayed heifers during late summer grazing. Colorado State Univ. Beer Prug. Rep. pp. 117-120. 